\title{
Recent advances in understanding noroviruses [version 1;
}

\section{peer review: 2 approved]}

\author{
Eric Bartnicki, Juliana Bragazzi Cunha(D), Abimbola O. Kolawole, \\ Christiane E. Wobus
}

Department of Microbiology and Immunology, University of Michigan Medical School, Ann Arbor, MI, USA

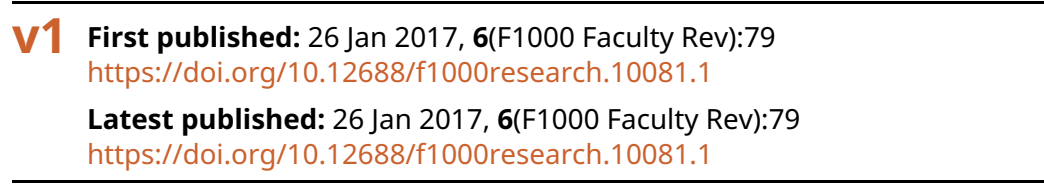

\section{Abstract}

Noroviruses are the leading cause of acute gastroenteritis around the world. An individual living in the United States is estimated to develop norovirus infection five times in his or her lifetime. Despite this, there is currently no antiviral or vaccine to combat the infection, in large part because of the historical lack of cell culture and small animal models. However, the last few years of norovirus research were marked by a number of ground-breaking advances that have overcome technical barriers and uncovered novel aspects of norovirus biology. Foremost among them was the development of two different in vitro culture systems for human noroviruses. Underappreciated was the notion that noroviruses infect cells of the immune system as well as epithelial cells within the gastrointestinal tract and that human norovirus infection of enterocytes requires or is promoted by the presence of bile acids. Furthermore, two proteinaceous receptors are now recognized for murine norovirus, marking the first discovery of a functional receptor for any norovirus. Recent work further points to a role for certain bacteria, including those found in the gut microbiome, as potential modulators of norovirus infection in the host, emphasizing the importance of interactions with organisms from other kingdoms of life for viral pathogenesis. Lastly, we will highlight the adaptation of drop-based microfluidics to norovirus research, as this technology has the potential to reveal novel insights into virus evolution. This review aims to summarize these new findings while also including possible future directions.

\section{Keywords}

RNA virus, Calicivirus, Norovirus, Viral Tropism, Viral Entry, Microbiome, Gastroenteritis, microfluidics

\section{Open Peer Review}

Approval Status

1 2

version 1

26 Jan 2017

Faculty Reviews are review articles written by the prestigious Members of Faculty Opinions. The articles are commissioned and peer reviewed before publication to ensure that the final, published version is comprehensive and accessible. The reviewers who approved the final version are listed with their names and affiliations.

1. Grant Hansman, Heidelberg University, Heidelberg, Germany

2. Jan Vinjé, Centers for Disease Control and Prevention, Atlanda, USA

Any comments on the article can be found at the end of the article. 
Corresponding author: Christiane E. Wobus (cwobus@umich.edu)

Competing interests: The authors declare that they have no competing interests.

Grant information: The author(s) declared that no grants were involved in supporting this work.

Copyright: $\odot 2017$ Bartnicki E et al. This is an open access article distributed under the terms of the Creative Commons Attribution License, which permits unrestricted use, distribution, and reproduction in any medium, provided the original work is properly cited. Data associated with the article are available under the terms of the Creative Commons Zero "No rights reserved" data waiver (CC0 1.0 Public domain dedication).

How to cite this article: Bartnicki $\mathrm{E}$, Cunha JB, Kolawole $\mathrm{AO}$ and Wobus $\mathrm{CE}$. Recent advances in understanding noroviruses [version 1; peer review: 2 approved] F1000Research 2017, 6(F1000 Faculty Rev):79 https://doi.org/10.12688/f1000research.10081.1

First published: 26 Jan 2017, 6(F1000 Faculty Rev):79 https://doi.org/10.12688/f1000research.10081.1 


\section{Introduction}

Noroviruses form a genus within the Caliciviridae family that is subdivided into seven genogroups $(\mathrm{G})$ and more than 30 genotypes ${ }^{1}$. These non-enveloped viruses have a positive-sense, single-stranded RNA genome $\sim 7.7 \mathrm{~kb}$ in size that is typically organized into three open reading frames (ORFs) ${ }^{2}$. ORF1 encodes the non-structural proteins; ORF2 encodes VP1, the major capsid protein; and ORF3 encodes VP2, the minor capsid protein ${ }^{3}$. Murine noroviruses also have a fourth ORF, which encodes an antagonist of the innate immune response called virulence factor $1(\mathrm{VF} 1)^{4}$. The major capsid protein VP1 forms virions and is divided in two domains: the shell (S) domain, which encases the viral RNA, and the protruding (P) domain ${ }^{5}$. The $\mathrm{P}$ domain interacts with the carbohydrate attachment receptors, contains neutralizing epitopes, and evolves under immune selection pressure ${ }^{6-8}$.

Human noroviruses are the leading etiologic agent of viral gastroenteritis globally in people of all ages ${ }^{9,10}$, costing $\sim 4$ billion US dollars in direct healthcare costs and $\sim 60$ billion US dollars in societal costs (e.g. lost productivity) worldwide ${ }^{11}$. These infections cause an estimated 200,000 deaths annually in children under 5 years of age in developing countries ${ }^{12}$. In the US alone, human noroviruses are estimated to annually cause 19-21 million infections and cost $\sim 2$ billion US dollars/year ${ }^{13,14}$. The majority of these infections are caused by GII, genotype 4 viruses (GII.4) ${ }^{15}$. However, no directed disease prevention and treatment modalities are available. This is in part because of historical limitations in working with these viruses in the laboratory. However, recent breakthroughs are overcoming previous challenges: for example, the development of two in vitro culture systems ${ }^{16,17}$, a mouse model ${ }^{18}$ and the identification of functional receptors for murine norovirus ${ }^{19,20}$. This review aims to summarize current knowledge about norovirus tropism, cellular entry, interactions with commensal bacteria, and the application of drop-based microfluidics to the analysis of viral evolution ${ }^{21-24}$. Owing to length restrictions, we are unable to cover all of the exciting advances in the norovirus field. However, the reader is referred to other excellent recent reviews for examples of norovirus replication ${ }^{25}$, norovirus antiviral and vaccine development ${ }^{26-28}$, and norovirus epidemiology and disease burden $^{29}$.

\section{Norovirus cell tropism}

Norovirus cell tropism has long been debated in the field ${ }^{30}$. The first culture system for a norovirus was described for murine norovirus in murine macrophages and dendritic cells following the observation that these cell types were infected in STAT1-deficient mice in vivo ${ }^{31}$. Subsequent work demonstrated an additional tropism of murine norovirus for murine $\mathrm{B}$ cells ${ }^{16}$, the extent of which is determined by residues in the VP1 P domain ${ }^{32}$. An immune cell tropism for human norovirus was also observed in some animal models ${ }^{18,33}$. While attempts at culturing human noroviruses in blood-derived macrophages and dendritic cells were unsuccessful ${ }^{34}$, some human B cell lines (BJAB, Raji, Namalwa) support infection with one strain (GII.4 Sydney) of human norovirus ${ }^{16,35}$. Additional studies are underway to test the susceptibility of these cell lines to additional human norovirus strains and genotypes. Nevertheless, subsequent work demonstrated the applicability of this first in vitro culture system for efficacy studies of human norovirus antivirals ${ }^{36}$, highlighting the power of this system for anti-norovirus drug development. In addition to the observed human norovirus infection of immune cells, an intestinal epithelial cell tropism of human norovirus has long been predicted, given the striking gastrointestinal symptoms and described perturbations of epithelial cells $^{37-40}$. However, previous attempts to cultivate human norovirus in intestinal epithelial cells in vitro were unsuccessful ${ }^{41-44}$. In contrast, a recent breakthrough describes the use of stem-cell-derived intestinal enteroids as another in vitro culture system for human noroviruses ${ }^{17}$. Enteroid cultures derived from stem cells from the duodenum, jejunum, or ileum are susceptible to human norovirus infection when the cells are matured into a monolayer. Unlike BJAB B cells ${ }^{16}$, human norovirus-infected intestinal epithelial cells exhibit cytopathic effects ${ }^{17}$. VP1 capsid protein staining revealed that specifically enterocytes, but not goblet cells or enteroendocrine cells, are infected. Interestingly, treatment of monolayers with bile acids was required for infection by some strains (e.g. GII.3), while it was not required but did improve infection by other strains (e.g. GII.4). Great variability was observed in overall viral titers between different strains and isolates ranging from 10-1000-fold. Viral titers typically increase $\sim 10-300$-fold in either in vitro culture system-thus, a direct comparison of the same virus stock in both systems is needed to determine whether one system supports greater replication levels than the other. The strength of the BJAB system lies in its simplicity and ease of use once established. However, further efforts are needed to overcome the variabilities seen between laboratories ${ }^{35}$. While the enteroid system is known to support the replication of multiple human norovirus strains and isolates, establishment and use of the system is costly and time intensive. Nevertheless, the exciting discovery of two human norovirus in vitro culture systems provides a technological advance for much-needed basic and translational studies in the future.

The dual tropism of human norovirus for B cells and enterocytes in vitro raises questions about the nature of the human norovirusinfected cell types in vivo. Intriguing new data obtained from immunostained small intestinal sections of human norovirus-infected patients ${ }^{45}$ are consistent with a dual tropism for immune cells and intestinal epithelial cells. Specifically, these data demonstrate the expression of structural and/or nonstructural proteins in cells positive for CD68 or DC-SIGN (i.e. macrophages and dendritic cells), CD3 (i.e. intraepithelial lymphocytes and T cells), and villin (i.e. enterocytes). This tropism for multiple cell types is also reminiscent of bovine norovirus, where capsid antigen was detected in villus enterocytes and in lamina propria immune cells ${ }^{46}$. The temporal expression of bovine norovirus antigen, first in epithelial cells and subsequently in immune cells ${ }^{46}$, as well as detection of the epithelial marker cytokeratin 8 in human norovirus-infected macrophages ${ }^{45}$ were interpreted as evidence for phagocytosis of infected epithelial cells by antigen-presenting cells. However, given the normal phagocytic function of these cells, direct viral infection of antigenpresenting cells cannot be ruled out. Unfortunately, the question of whether human B cells are infected in vivo could not be addressed since CD20+ B cells were not detectable in the histologic sections of human norovirus-infected immunodeficient patients ${ }^{45}$. However, the finding that human SCID patients who lack B cells are able to be infected with human norovirus is consistent with a tropism for multiple cell types, including B cells ${ }^{47}$. The viral titer of these patients was approximately one log lower compared to patients with 
B cells, suggesting that B cells contribute to the overall viral loads. Taken together, B cells, in addition to enterocytes, are an important player in human norovirus pathogenesis, although their precise contribution and viral factors in that process remain to be elucidated. For murine norovirus, the interaction with B cells is multi-faceted. Early in infection, the murine norovirus minor capsid protein VP2 antagonizes B cell antigen presentation to CD8 cytotoxic T cells in a strain-specific manner ${ }^{32}$. Later in infection, antibody is critical for the clearance of murine norovirus infection ${ }^{48}$. Further studies are clearly required to elucidate the role of each target cell type and the temporal pattern of infection during norovirus pathogenesis, as well as the contribution of viral factors to any phenotype. Furthermore, the susceptibility of enterocytes to murine norovirus should be revisited.

\section{Norovirus binding and entry}

In general, viral infection of susceptible target cells is a multistep process that begins with the binding of viral particles to attachment receptors, which helps to concentrate the particles on the cell surface ${ }^{49}$. Subsequent interaction with additional receptor molecules (e.g. functional or entry receptors) actively promotes virus uptake: for example, by initiating conformational changes in the virus capsid, activating cellular signaling, promoting endocytosis, or directly driving penetration ${ }^{49,50}$. Although little is known about norovirus entry, we hypothesize that the entry process is likely characterized by similar features.

The attachment receptors for most human noroviruses are histoblood group antigens (HBGAs), terminal complex carbohydrates of lipid- or protein-linked glycan chains ${ }^{51-53}$. HBGAs are expressed on multiple cells types, including intestinal epithelial cells, and secreted into body fluids, such as saliva ${ }^{51,54}$. Two to four binding sites within the human norovirus P dimer bind to $\alpha 1$,2-linked fucose on HBGAs, a residue attached to the carbohydrate core by the $\alpha(1,2)$ fucosyltransferase (FUT2) enzyme ${ }^{55-59}$. Individuals with a functional FUT2 enzyme are termed secretors, while those without are known as non-secretors. Secretors are more susceptible to many human norovirus strains (e.g. GII.4) and other diarrheal diseases ${ }^{60-63}$. In culture, GII.4 strains of human norovirus infect enteroids derived from secretor but not non-secretor individuals ${ }^{17}$, suggesting that susceptibility to norovirus infection is determined at the level of the cell. One potential mechanism of promoting infection may be by enhancing cell attachment, since synthetic HBGAs or enteric bacteria expressing HBGA-like structures increase viral attachment to B cells ${ }^{16}$. However, the precise role(s) that specific HBGAs play in different locations in the body, or when attached to different cores from host or enteric bacteria, remains to be addressed in future studies. Studies to date have investigated HBGA-linked lipids. Glycosphingolipids (GSLs), including those containing HBGA, are a main constituent of the plasma membrane of many cells. The ceramide base anchors GSLs to the membrane, while the glycan group extends into the extracellular space ${ }^{64}$. GSLs serve as attachment receptors for multiple non-enveloped viruses (e.g. rotavirus and polyomavirus) ${ }^{65}$. Depending on the strain, human norovirus virus-like particles (VLPs) can bind to the HBGA groups of $\mathrm{GSL}^{66}$ but also to the galactose-containing GSL galactosylceramide ${ }^{67}$ or gangliosides ${ }^{68}$, which are sialic-acidcontaining GSLs. Similarly, murine norovirus binds to gangliosides on murine macrophages, specifically the terminal sialic acid of
GD1a, in the case of the MNV-1 strain ${ }^{69}$. The interaction between human norovirus particles and the cellular membrane GSLs occurs only above a certain threshold concentration of HBGAGSL and in a virus strain-specific manner ${ }^{70}$. This interaction then clusters the GSLs to form a lipid microdomain and causes invagination of that membrane region ${ }^{71}$. The downstream events of human norovirus cellular entry are still unknown and await further study in the recently developed cell culture systems ${ }^{16,17}$. Endocytosis of murine norovirus particles is dependent on dynamin II, ceramide, and cholesterol but is independent of clathrin, caveolin, and $\mathrm{pH}^{72-74}$. Ceramide is the backbone of GSL structures ${ }^{75}$, while cholesterol stabilizes lipid microdomains ${ }^{76}$. Therefore, it is possible that, like murine norovirus, human norovirus entry will also depend on these two factors. Interestingly, human norovirus infection is dependent on, or enhanced by, bile acids in enteroid cultures $^{17}$. Bile acids can directly induce ceramide production by activating the farnesoid $\mathrm{X}$ receptor $(\mathrm{FXR})^{77,78}$, a nuclear receptor expressed in many tissues, including in the intestine and immune cells ${ }^{79,80}$. FXR induction, in turn, increases the expression of enzymes involved in the production of ceramide, including Smdp3 (neutral sphingomyelinase II) and Smpd4 (neutral sphingomyelinase III $)^{78}$, which form ceramide after hydrolyzing sphingomyelin ${ }^{81}$. Ceramide then transactivates glucosylceramide synthase expression, which generates glucosylceramide, the starting point for GSL biosynthesis ${ }^{82,83}$. A larger quantity of ceramide in a cell may thus facilitate the production of GSL attachment receptors for noroviruses, providing a potential explanation for the dependence of these viruses on bile acids or ceramide.

Other recent studies have described the discovery of multiple proteins involved in murine norovirus binding and entry. CD36, CD98, transferrin receptor, and CD44 are cell-type-specific modulators of murine norovirus infection in murine macrophages and murine dendritic cells, though the mechanism by which these proteins aid in infection awaits further study ${ }^{84}$. An exciting discovery was the identification of CD3001f and CD3001d as the murine norovirus entry receptors ${ }^{19,20}$, the first and, to date, only functional receptors known in the norovirus genus. CD300lf was identified as a critical protein during murine norovirus infection in CRISPR-Cas9 screens in BV2 ${ }^{20}$ and RAW264.7 cells ${ }^{19}$. The murine norovirus binding site on CD300lf was mapped to amino acids 39 to 45 at the protein's $\mathrm{N}$-terminus. This is a region completely conserved in the related family member CD300ld, providing an explanation for the ability of murine norovirus to bind to both molecules ${ }^{19}$. Transfection of murine CD300lf or CD300ld into non-susceptible but permissive HeLa and HEK293T human cell lines rendered these cells susceptible to murine norovirus infection ${ }^{19,20}$. However, transfection of human CD300lf into murine cells did not mediate murine norovirus susceptibility ${ }^{20}$, suggesting that CD300lf is a receptor determining both cell tropism and species specificity. Whether human CD300lf or CD300ld serve as a receptor for human norovirus remains to be determined. CD300 proteins, like the only other known functional receptor in the Caliciviridae family, JAM-A, are part of the Ig superfamily of proteins ${ }^{85,86}$. Clustering in lipid raft domains is essential for CD300 protein function ${ }^{87}$, providing a potential interaction platform between norovirus attachment and functional receptors at the cellular level. In vivo, Cd300lf deletion renders mice resistant to shedding following oral murine norovirus infection ${ }^{20}$. However, the precise role of CD300lf during 
pathogenesis remains to be investigated. Expression of CD300lf can be induced by conditions known to induce microfold (M) cell differentiation ${ }^{88}$. Since these cells are important for murine norovirus transcytosis across intestinal epithelial layers in vitro and in vivo ${ }^{89-91}$, this suggests CD300lf may function in a cell-type-specific manner. CD300ld regulates the expression of other CD300 molecules ${ }^{85}$ and stimulates macrophages to secrete pro-inflammatory cytokines and chemokines ${ }^{92}$. In macrophages, antibody cross-linking of CD300ld increases the secretion of TNF- $\alpha$ and IL- ${ }^{93}$, two pro-inflammatory cytokines also upregulated during human norovirus infection in vivo ${ }^{94,95}$. Future investigations are needed to investigate the roles of CD300lf and/or CD300ld in species specificity of norovirus infection, norovirus cellular and tissue tropism, and murine norovirus transcytosis through $\mathrm{M}$ cells and pathogenesis.

Taken together, one possible model of norovirus entry might be as follows. Norovirus virions bind to one or several GSLs on the host cell surface, allowing for viral adhesion to and movement along the fluid surface of the plasma membrane. The multivalent particles then bind more GSLs, which are present in already formed lipid domains, such as lipid rafts, or newly form a cluster of lipids at the interaction site between the virus particle and the cell membrane. Transmembrane proteins such as CD300 proteins ${ }^{87}$ may already be resident in lipid rafts or may be recruited to the microdomain induced by norovirus particle binding. This could create a stable, cholesterol-dependent platform for noroviruses to promote engagement with signaling molecules and the functional receptor. The multivalency of the norovirus capsid in concert with GSLs may cause invagination of the plasma membrane ${ }^{71}$. Norovirus-containing vesicles may next be released from the plasma membrane by dynamin II-mediated scission of the invagination, followed in quick succession by viral genome release into the cytosol ${ }^{73}$. Although the past 10 years have shed light on some aspects of norovirus entry, much still remains to be addressed, such as the interplay between different norovirus receptors, potential conformational changes in the virus capsid, potential activation of cellular signaling, and the mechanism of membrane penetration.

\section{Norovirus and the intestinal microbiome}

Recent studies have led to an appreciation that infection by enteric viruses, including noroviruses, is influenced by the commensal microbiota ${ }^{16,96,97}$. While a mechanistic understanding of these transkingdom encounters is still lacking, the proviral or antiviral functions of the microbiota are both direct and indirect ${ }^{98}$. In the case of noroviruses, one example for a direct effect is the enhancement of GII.4 human norovirus infection of B cells by the commensal bacterium SENG-6, an Enterobacter cloacae strain ${ }^{16}$. This effect is mediated, at least in part, by increasing cell attachment via bacterially expressed HBGA-like molecules. Other bacterial species similarly express HBGA-like structures ${ }^{99}$ and thus might also be able to stimulate infection in vitro, although this still needs to be tested experimentally in both culture systems. The opposite was observed in vivo during infection of gnotobiotic pigs, where E. cloacae inhibited human norovirus infection, compared to uncolonized pigs ${ }^{100}$. However, the study lacked an important control (namely, a bacterial strain unable to bind human norovirus) and thus the effect of E. cloacae on norovirus infection in vivo remains unclear. Another proviral direct effect of bacteria during norovirus infection is via increasing particle stability and protecting virions from heat stress $^{99}$. This may promote viral transmission and environmental fitness similar to poliovirus ${ }^{101}$, but future studies are required to directly test this.

Indirect mechanisms are thought to occur via modulation of the antiviral immune response by the microbiota. This is consistent with the observed increase in murine norovirus loads in the ileum of conventional mice compared to antibiotic-treated or germ-free mice ${ }^{16,102}$ and the type III interferon-mediated changes in murine norovirus persistence ${ }^{103}$. In contrast to the proviral effects of the microbiota, at least one bacterial genus, Lactobacillus, can also play a protective role against norovirus infections. A higher abundance of Lactobacillus due to probiotic-fermented milk ingestion correlates with a quicker recovery from human norovirus-induced fever ${ }^{104}$. Similarly, a higher abundance of Lactobacillus following experimental vitamin A treatment correlates with inhibition of murine norovirus infection ${ }^{105}$. These initial observations suggest that the microbiota and its members can be either protective or stimulatory for norovirus infections. Another indirect effect may also occur through the modulation of glycan molecules that mediate viral attachment. Specifically, intestinal colonization with the microbiota upregulates fut 2 expression via ERK and JNK signaling cascades ${ }^{106}$, while colonization with CagA-positive Helicobacter pylori correlates with $\alpha(1,2)$ fucosylated epitopes on intestinal surfaces ${ }^{107}$. Since an individual's secretor status influences their microbiota composition ${ }^{108,109}$, there appears to be a reciprocal relationship between the host and bacteria that determine the overall level of fucosylation in the intestine ${ }^{110}$. The modulation of receptor binding sites may also extend to proteinaceous receptors. The murine norovirus receptor CD300lf is upregulated by lipopolysaccharide (LPS) stimulation $^{111,112}$. Thus, Gram-negative bacteria might upregulate this viral receptor. Engagement of CD3001f can also upregulate TNF- $\alpha$ expression ${ }^{113}$, which may explain the observed TNF- $\alpha$ increase during human and murine norovirus infection ${ }^{94,114,115}$. Interestingly, TNF- $\alpha$ induces sialyltransferase activity ${ }^{116,117}$ as well as lactosylceramide synthase activity, an enzyme that produces lactosylceramide from glucosylceramide, a precursor for most glycosphingolipids ${ }^{118}$. Therefore, engagement of inflammatory pathways may upregulate gangliosides and sialic acids on the cell surface, known murine norovirus attachment factors ${ }^{69,119}$. This might provide an explanation for why murine norovirus does not share the same level of dependence on the presence of bile acids as do human noroviruses ${ }^{17,74}$. Yet both viruses may have evolved ways to promote upregulation of host receptor molecules to facilitate infection. Clearly, more studies are needed to investigate these potential links and gain a mechanistic understanding of the multifaceted role of the microbiota on norovirus infections.

\section{Microfluidics in norovirus research}

An exciting technical development in the field is the application of drop-based microfluidics to norovirus research. This ultrahighthroughput platform uses aqueous drops dispersed in oil as picoliter-volume reaction vessels to screen and analyze single cells or individual virus particles at a rate and level of sensitivity that are far superior to the traditional cell-culture-based techniques 
used currently, such as plaque assay, and other biochemical-, genetic-, and molecular-based techniques ${ }^{21,22,120-124}$. The production of millions of drops that are amenable to high-speed measurements in parallel reduces cost and screening time ${ }^{125,126}$. Furthermore, microfluidics overcome the loss of error due to the presence of minor alleles associated with bulk viral culture, since each encapsulated virus particle constitutes an independent experiment, facilitating viral evolution studies. Over the past five years, microfluidics has been successfully used to i) grow murine norovirus to identify mutations that support escape from neutralizing monoclonal antibody A6.2 22 , ii) develop a rapid, targeted, and culture-free infectivity assay to determine the efficacy of a neutralizing antibody for murine norovirus ${ }^{21}$ with comparable results to plaque-based neutralization assays, iii) detect, quantify, and sequence artifactfree rare recombinant noroviruses in vitro $^{24}$ and in vivo ${ }^{23}$, providing critical information that cannot be obtained using traditional methods such as phylogenetic studies ${ }^{127,128}$ and full genome sequencing $^{128}$, and, lastly, iv) simultaneously screen for multiple viruses, including noroviruses, in environmental water samples ${ }^{129,130}$. The microfluidics technology is continually being improved and adapted to a wider array of scientific inquiries ${ }^{121}$ and has the potential to become an integral platform for future norovirus research, specifically aiding in studies of norovirus evolution and population dynamics, drug screening, and environmental testing.

\section{Conclusion}

Noroviruses have proven difficult to study in the past, but progress in overcoming technical barriers has opened doors to much-needed basic and translational studies. The recent development of two new culture systems has already yielded new biological findings about the role of bile acids and HBGAs in norovirus infection ${ }^{16,17}$. Further refinement of each system and improvements in ease of use and reproducibility will increase their utility to the scientific community and facilitate new discoveries. In addition, the identification of multiple norovirus-infected cell types of both epithelial (i.e. enterocytes) and immunological (e.g. B cells, macrophages, dendritic cells, and T cells) origin represents a shift in the paradigm from the assumed enterocyte-tropic nature of noroviruses to a more inclusive definition of an enterotropic virus: one that encompasses infection of multiple cell types residing in the intestine. Therefore, culture systems that recapitulate infection of each cell type will advance a greater understanding of the cell-type-specific vs. general mechanisms that drive norovirus infection. At the same time, the appreciation of this broader tropism also suggests that more advanced co-culture systems encompassing multiple cell types will be needed to dissect the interactions between norovirus and the various cell types and their specific roles in pathogenesis. In addition, early findings regarding the importance of intestinal microbiota and norovirus encounters on the outcome of infection provide an exciting new direction in the norovirus field, revealing interesting details about the complex interplay between highly different organisms. Combining the expertise of scientists within and outside the norovirus field to take advantage of new methodologies such as microfluidics will further increase our understanding of norovirus biology and our ability to develop effective solutions for infection prevention, treatment, and control.

\section{Competing interests}

The authors declare that they have no competing interests.

\section{Grant information}

Work in the laboratory of C.E.W. is funded by NIH R21 AI110907, U19-AI116482, and R33 AI102106. We thank Dr Karla Passalacqua for helpful comments.

\section{Acknowledgements}

We apologize to all colleagues whose work could not be cited because of length restrictions.
1. F Vinjé J: Advances in laboratory methods for detection and typing of norovirus. J Clin Microbiol. 2015; 53(2): 373-81.

PubMed Abstract | Publisher Full Text | Free Full Text | F1000 Recommendation

2. Glass RI, Parashar UD, Estes MK: Norovirus gastroenteritis. N Engl J Med. 2009; 361(18): 1776-85.

PubMed Abstract | Publisher Full Text | Free Full Text

3. Green KY: Caliciviridae: The Noroviruses. In: DM Knipe PH (ed), Fields Virology. 6 ed, Lippincott Williams \& Wilkins, Philadelphia. 2013; 1: 582-608.

4. McFadden N, Bailey D, Carrara G, et al.: Norovirus regulation of the innate immune response and apoptosis occurs via the product of the alternative open reading frame 4. PLoS Pathog. 2011; 7(12): e1002413. PubMed Abstract | Publisher Full Text | Free Full Text

5. Prasad BV, Hardy ME, Dokland T, et al:: X-ray crystallographic structure of the Norwalk virus capsid. Science. 1999; 286(5438): 287-90. PubMed Abstract | Publisher Full Text

6. Singh BK, Leuthold MM, Hansman GS: Structural Constraints on Human Norovirus Binding to Histo-Blood Group Antigens. mSphere. 2016; 1(2): pii: e00049-16.

PubMed Abstract | Publisher Full Text | Free Full Text

7. Tan $M$, Jiang $X$ : Norovirus gastroenteritis, carbohydrate receptors, and animal models. PLoS Pathog. 2010; 6(8): e1000983.

PubMed Abstract | Publisher Full Text | Free Full Text

8. Debbink K, Donaldson EF, Lindesmith LC, et al:: Genetic mapping of a highly variable norovirus Gll.4 blockade epitope: potential role in escape from human herd immunity. J Virol. 2012; 86(2): 1214-26.

PubMed Abstract | Publisher Full Text | Free Full Text

9. Widdowson MA, Monroe SS, Glass RI: Are noroviruses emerging? Emerg Infect Dis. 2005; 11(5): 735-7.

PubMed Abstract | Publisher Full Text | Free Full Text

10. Centers for Disease Control and Prevention (CDC): Norovirus activity--United States, 2006-2007. MMWR Morb Mortal Wkly Rep. 2007; 56(33): 842-6. PubMed Abstract

11. F Bartsch SM, Lopman BA, Ozawa S, et al:: Global Economic Burden of Norovirus Gastroenteritis. PLoS One. 2016; 11(4): e0151219.

PubMed Abstract | Publisher Full Text | Free Full Text | F1000 Recommendation

12. Patel MM, Widdowson M, Glass RI, et al:: Systematic literature review of role of noroviruses in sporadic gastroenteritis. Emerg Infect Dis. 2008; 14(8): 1224-31. PubMed Abstract | Publisher Full Text | Free Full Text

13. Belliot G, Lopman BA, Ambert-Balay K, et al:: The burden of norovirus gastroenteritis: an important foodborne and healthcare-related infection. Clin Microbiol Infect. 2014; 20(8): 724-30. PubMed Abstract | Publisher Full Text

14. F Hall AJ, Lopman BA, Payne DC, et al:: Norovirus disease in the United States. Emerg Infect Dis. 2013; 19(8): 1198-205.

PubMed Abstract | Publisher Full Text | Free Full Text | F1000 Recommendation

15. F Vega E, Barclay L, Gregoricus N, et al:: Genotypic and epidemiologic trends 
of norovirus outbreaks in the United States, 2009 to 2013. J Clin Microbiol. 2014; 52(1): $147-55$

PubMed Abstract | Publisher Full Text | Free Full Text | F1000 Recommendation

16. Jones MK, Watanabe M, Zhu S, et al:: Enteric bacteria promote human and mouse norovirus infection of B cells. Science. 2014; 346(6210): 755-9. PubMed Abstract | Publisher Full Text | Free Full Text

17. F Ettayebi K, Crawford SE, Murakami K, et al:: Replication of human noroviruses in stem cell-derived human enteroids. Science. 2016; 353(6306): 1387-93.

PubMed Abstract | Publisher Full Text | F1000 Recommendation

18. Taube $\mathrm{S}$, Kolawole $\mathrm{AO}$, Hohne $\mathrm{M}$, et al: A mouse model for human norovirus MBio. 2013; 4(4): pii: e00450-13.

PubMed Abstract | Publisher Full Text | Free Full Text

19. F Haga K, Fujimoto A, Takai-Todaka R, et al.: Functional receptor molecules CD300lf and CD300ld within the CD300 family enable murine noroviruses to infect cells. Proc Natl Acad Sci U S A. 2016; 113(41): E6248-E6255. PubMed Abstract | Publisher Full Text | Free Full Text | F1000 Recommendation

20. F Orchard RC, Wilen CB, Doench JG, et al.: Discovery of a proteinaceous cellular receptor for a norovirus. Science. 2016; 353(6302): 933-6. PubMed Abstract | Publisher Full Text | F1000 Recommendation

21. Tao $\mathrm{Y}$, Rotem $\mathrm{A}$, Zhang $\mathrm{H}$, et al.: Rapid, targeted and culture-free viral infectivity assay in drop-based microfluidics. Lab Chip. 2015; 15(19): 3934-40. PubMed Abstract | Publisher Full Text

22. Fischer AE, Wu SK, Proescher JB, et al:: A high-throughput drop microfluidic system for virus culture and analysis. J Virol Methods. 2015; 213: 111-7. PubMed Abstract | Publisher Full Text

23. Zhang H, Cockrell SK, Kolawole AO, et al:: Isolation and Analysis of Rare Norovirus Recombinants from Coinfected Mice Using Drop-Based Microfluidics. J Virol. 2015; 89(15): 7722-34. PubMed Abstract | Publisher Full Text | Free Full Text

24. Tao Y, Rotem A, Zhang H, et al:: Artifact-Free Quantification and Sequencing of Rare Recombinant Viruses by Using Drop-Based Microfluidics. Chembiochem. 2015; 16(15): 2167-71. PubMed Abstract | Publisher Full Text

25. F Thorne LG, Goodfellow IG: Norovirus gene expression and replication J Gen Virol. 2014; 95(Pt 2): 278-91. PubMed Abstract | Publisher Full Text | F1000 Recommendation

26. F Thorne L, Arias A, Goodfellow I: Advances Toward a Norovirus Antiviral: From Classical Inhibitors to Lethal Mutagenesis. J Infect Dis. 2016; 213(Suppl 1): S27-31.

PubMed Abstract | Publisher Full Text | Free Full Text | F1000 Recommendation

27. F Rocha-Pereira J, Neyts J, Jochmans D: Norovirus: targets and tools in antiviral drug discovery. Biochem Pharmacol. 2014; 91(14): 1-11. PubMed Abstract | Publisher Full Text | F1000 Recommendation

28. F Prasad BV, Shanker S, Muhaxhiri Z, et al:: Antiviral targets of human noroviruses. Curr Opin Virol. 2016; 18: 117-25

PubMed Abstract | Publisher Full Text | Free Full Text | F1000 Recommendation

29. F Lopman BA, Steele D, Kirkwood CD, et al:: The Vast and Varied Global Burden of Norovirus: Prospects for Prevention and Control. PLoS Med. 2016; 13(4): e1001999.

PubMed Abstract | Publisher Full Text | Free Full Text | F1000 Recommendation

30. Karst SM, Wobus CE, Goodfellow IG, et al.: Advances in norovirus biology. Cell Host Microbe. 2014; 15(6): 668-80.

PubMed Abstract | Publisher Full Text | Free Full Text

31. Wobus CE, Karst SM, Thackray LB, et al:: Replication of Norovirus in cell culture reveals a tropism for dendritic cells and macrophages. PLOS Biol. 2004; 2(12): e432.

PubMed Abstract | Publisher Full Text | Free Full Text

32. Zhu S, Jones MK, Hickman D, et al.: Norovirus antagonism of B-cell antigen presentation results in impaired control of acute infection. Mucosal Immunol. 2016; 9(6): 1559-70.

PubMed Abstract | Publisher Full Text | Free Full Text

33. Bok K, Parra GI, Mitra T, et al: Chimpanzees as an animal model for human norovirus infection and vaccine development. Proc Natl Acad Sci U S A. 2011; 108(1): 325-30.

PubMled Abstract | Publisher Full Text | Free Full Text

34. Lay MK, Atmar RL, Guix S, et al:: Norwalk virus does not replicate in human macrophages or dendritic cells derived from the peripheral blood of susceptible humans. Virology. 2010; 406(1): 1-11.

PubMed Abstract | Publisher Full Text | Free Full Text

35. Jones MK, Grau KR, Costantini V, et al:: Human norovirus culture in B cells. Nat Protoc. 2015; 10(12): 1939-47.

PubMed Abstract | Publisher Full Text | Free Full Text

36. Kolawole AO, Rocha-Pereira J, Elftman MD, et al.: Inhibition of human norovirus by a viral polymerase inhibitor in the $B$ cell culture system and in the mouse model. Antiviral Res. 2016; 132: 46-9.

PubMed Abstract | Publisher Full Text | Free Full Text

37. Dolin R, Levy AG, Wyatt RG, et al:: Viral gastroenteritis induced by the Hawaii agent. Jejunal histopathology and serologic response. Am J Med. 1975; 59(6): 761-8.

PubMed Abstract | Publisher Full Text
38. $\mathrm{F}$ Troeger $\mathrm{H}$, Loddenkemper $\mathrm{C}$, Schneider $\mathrm{T}$, et al.: Structural and functional changes of the duodenum in human norovirus infection. Gut. 2009; 58(8): $1070-7$.

PubMed Abstract | Publisher Full Text | F1000 Recommendation

39. Acute infectious nonbacterial gastroenteritis: etiology and pathogenesis. Ann Intern Med. 1972; 76(6): 993-1008. PubMed Abstract | Publisher Full Text

40. Schreiber DS, Blacklow NR, Trier JS: The small intestinal lesion induced by Hawaii agent acute infectious nonbacterial gastroenteritis. J Infect Dis. 1974; 129(6): 705-8.

PubMed Abstract | Publisher Full Text

41. Duizer E, Schwab KJ, Neill FH, et al.: Laboratory efforts to cultivate noroviruses. J Gen Virol. 2004; 85(Pt 1): 79-87.

PubMed Abstract | Publisher Full Text

42. Takanashi S, Saif LJ, Hughes JH, et al:: Failure of propagation of human norovirus in intestinal epithelial cells with microvilli grown in threedimensional cultures. Arch Virol. 2014; 159(2): 257-66. PubMed Abstract | Publisher Full Text | Free Full Text

43. Papafragkou E, Hewitt J, Park GW, et al.: Challenges of culturing human norovirus in three-dimensional organoid intestinal cell culture models. PLOS One. 2013; 8(6): e63485.

PubMed Abstract | Publisher Full Text | Free Full Text

44. Herbst-Kralovetz MM, Radtke AL, Lay MK, et al.: Lack of norovirus replication and histo-blood group antigen expression in 3-dimensional intestinal epithelial cells. Emerg Infect Dis. 2013; 19(3): 431-8. PubMed Abstract | Publisher Full Text | Free Full Text

45. F Karandikar UC, Crawford SE, Ajami NJ, et al.: Detection of human norovirus in intestinal biopsies from immunocompromised transplant patients. $J$ Gen Virol. 2016; 97(9): 2291-300.

PubMed Abstract | Publisher Full Text | F1000 Recommendation

46. F Otto PH, Clarke IN, Lambden PR, et al:: Infection of calves with bovine norovirus GIIl.1 strain Jena virus: an experimental model to study the pathogenesis of norovirus infection. J Virol. 2011; 85(22): 12013-21. PubMed Abstract | Publisher Full Text | Free Full Text | F1000 Recommendation

47. F Brown JR, Gilmour K, Breuer J: Norovirus Infections Occur in B-CellDeficient Patients. Clin Infect Dis. 2016; 62(9): 1136-8.

PubMed Abstract | Publisher Full Text | F1000 Recommendation

48. Chachu KA, Strong DW, LoBue AD, et al:: Antibody is critical for the clearance of murine norovirus infection. J Virol. 2008; 82(13): 6610-7. PubMed Abstract | Publisher Full Text | Free Full Text

49. Mercer J, Schelhaas M, Helenius A: Virus entry by endocytosis. Annu Rev Biochem. 2010; 79: 803-33.

PubMed Abstract | Publisher Full Text

50. Grove J, Marsh M: The cell biology of receptor-mediated virus entry. J Cell Biol. 2011; 195(7): 1071-82.

PubMed Abstract | Publisher Full Text | Free Full Text

51. Marionneau S, Cailleau-Thomas A, Rocher J, et al:: ABH and Lewis histo-blood group antigens, a model for the meaning of oligosaccharide diversity in the face of a changing world. Biochimie. 2001; 83(7): 565-73.

PubMed Abstract | Publisher Full Text

52. Tan $\mathrm{M}$, Jiang $\mathrm{X}$ : Norovirus and its histo-blood group antigen receptors: an answer to a historical puzzle. Trends Microbiol. 2005; 13(6): 285-93. PubMled Abstract | Publisher Full Text

53. Ravn V, Dabelsteen $\mathrm{E}$ : Tissue distribution of histo-blood group antigens. APMIS. 2000; 108(1): 1-28. PubMed Abstract | Publisher Full Text

54. Henry SM, Samuelsson BE, Oriol R: Immunochemical and immunohistological expression of Lewis histo-blood group antigens in small intestine including individuals of the Le $(a+b+)$ and Le(a-b-) nonsecretor phenotypes. Glycoconj J. 1994; 11(6): 600-7. PubMed Abstract | Publisher Full Text

55. F Cao S, Lou Z, Tan M, et al:: Structural basis for the recognition of blood group trisaccharides by norovirus. J Virol. 2007; 81(11): 5949-57. PubMed Abstract | Publisher Full Text | Free Full Text | F1000 Recommendation

56. $\mathrm{F}$ Koromyslova AD, Leuthold MM, Bowler MW, et al.: The sweet quartet: Binding of fucose to the norovirus capsid. Virology. 2015; 483: 203-8. PubMed Abstract | Publisher Full Text | F1000 Recommendation

57. F Tan M, Jiang X: Histo-blood group antigens: a common niche for norovirus and rotavirus. Expert Rev Mol Med. 2014; 16: e5.

PubMed Abstract | Publisher Full Text | F1000 Recommendation

58. F Mallagaray A, Rademacher C, Parra F, et al: Saturation transfer difference nuclear magnetic resonance titrations reveal complex multistep-binding of l-fucose to norovirus particles. Glycobiology. 2017; 27(1): 80-86. PubMed Abstract | Publisher Full Text | F1000 Recommendation

59. F Mallagaray A, Lockhauserbäumer J, Hansman G, et al:: Attachment of norovirus to histo blood group antigens: a cooperative multistep process. Angew Chem Int Ed Engl. 2015; 54(41): 12014-9. PubMed Abstract | Publisher Full Text | F1000 Recommendation

60. F Bustamante M, Standl M, Bassat $\mathrm{Q}$, et al.: A genome-wide association meta-analysis of diarrhoeal disease in young children identifies FUT2 locus 
and provides plausible biological pathways. Hum Mol Genet. 2016; pii: ddw264 PubMed Abstract | Publisher Full Text | F1000 Recommendation

61. F Currier RL, Payne DC, Staat MA, et al:: Innate Susceptibility to Norovirus Infections Influenced by FUT2 Genotype in a United States Pediatric Population. Clin Infect Dis. 2015; 60(11): 1631-8. PubMed Abstract | Publisher Full Text | Free Full Text | F1000 Recommendation

62. Kindberg E, Akerlind B, Johnsen C, et al.: Host genetic resistance to symptomatic norovirus (GGll.4) infections in Denmark. J Clin Microbiol. 2007; 45(8): 2720-2

PubMed Abstract | Publisher Full Text | Free Full Text

63. $\mathrm{F}$ Lindesmith $\mathrm{L}$, Moe $\mathrm{C}$, Marionneau $\mathrm{S}$, et al:: Human susceptibility and resistance to Norwalk virus infection. Nat Med. 2003; 9(5): 548-53. PubMed Abstract | Publisher Full Text | F1000 Recommendation

64. Iwabuchi K, Nakayama H, Oizumi A, et al:: Role of Ceramide from Glycosphingolipids and Its Metabolites in Immunological and Inflammatory Responses in Humans. Mediators Inflamm. 2015; 2015: 120748. PubMed Abstract | Publisher Full Text | Free Full Text

65. Taube S, Jiang M, Wobus CE: Glycosphingolipids as receptors for non-enveloped viruses. Viruses. 2010; 2(4): 1011-49. PubMed Abstract | Publisher Full Text | Free Full Text

66. Nilsson J, Rydell GE Le Pendu J, et al: Norwalk virus-like particles bind specifically to $A, H$ and difucosylated Lewis but not to $B$ histo-blood group active glycosphingolipids. Glycoconj J. 2009; 26(9): 1171-80. PubMed Abstract | Publisher Full Text

67. Bally M, Rydell GE, Zahn R, et al.: Norovirus Gll.4 virus-like particles recognize galactosylceramides in domains of planar supported lipid bilayers. Angew Chem Int Ed Engl. 2012; 51(48): 12020-4. PubMed Abstract | Publisher Full Text | Free Full Text

68. Han L, Tan M, Xia M, et al:: Gangliosides are ligands for human noroviruses. J Am Chem Soc. 2014; 136(36): 12631-7.

PubMed Abstract | Publisher Full Text | Free Full Text

69. Taube S, Perry JW, Yetming K, et al:: Ganglioside-linked terminal sialic acid moieties on murine macrophages function as attachment receptors for murine noroviruses. J Virol. 2009; 83(9): 4092-101.

PubMed Abstract | Publisher Full Text | Free Full Text

70. Rydell GE, Dahlin AB, Höök F, et al:: QCM-D studies of human norovirus VLPs binding to glycosphingolipids in supported lipid bilayers reveal strain-specific characteristics. Glycobiology. 2009; 19(11): 1176-84.

PubMed Abstract | Publisher Full Text

71. F Rydell GE, Svensson L, Larson G, et al.: Human GIl.4 norovirus VLP induces membrane invaginations on giant unilamellar vesicles containing secretor gene dependent $\mathbf{1 1 , 2 - f u c o s y l a t e d ~ g l y c o s p h i n g o l i p i d s . ~ B i o c h i m ~ B i o p h y s ~ A c t a . ~}$ 2013; 1828(8): 1840-5.

PubMed Abstract | Publisher Full Text | F1000 Recommendation

72. Perry JW, Taube S, Wobus CE: Murine norovirus-1 entry into permissive macrophages and dendritic cells is pH-independent. Virus Res. 2009; 143(1): $125-9$.

PubMed Abstract | Publisher Full Text | Free Full Text

73. Perry JW, Wobus CE: Endocytosis of murine norovirus 1 into murine macrophages is dependent on dynamin II and cholesterol. J Virol. 2010; 84(12): 6163-76.

PubMed Abstract | Publisher Full Text | Free Full Text

74. Shivanna V, Kim Y, Chang KO: Ceramide formation mediated by acid sphingomyelinase facilitates endosomal escape of caliciviruses. Virology. 2015; 483: 218-28.

PubMed Abstract | Publisher Full Text | Free Full Text

75. D'Angelo G, Capasso S, Sticco L, et al:: Glycosphingolipids: synthesis and functions. FEBS J. 2013; 280(24): 6338-53. PubMed Abstract | Publisher Full Text

76. Prinetti A, Loberto N, Chigorno V, et al:: Glycosphingolipid behaviour in complex membranes. Biochim Biophys Acta. 2009; 1788(1): 184-93. PubMed Abstract | Publisher Full Text

77. F Mi L, Devarakonda S, Harp JM, et al:: Structural basis for bile acid binding and activation of the nuclear receptor FXR. Mol Cell. 2003; 11(4): 1093-100. PubMed Abstract | Publisher Full Text | F1000 Recommendation

78. Jiang C, Xie C, Lv Y, et al.: Intestine-selective farnesoid $\mathrm{X}$ receptor inhibition improves obesity-related metabolic dysfunction. Nat Commun. 2015; 6: 10166. PubMed Abstract | Publisher Full Text | Free Full Text

79. F Fang S, Suh JM, Reilly SM, et al.: Intestinal FXR agonism promotes adipos tissue browning and reduces obesity and insulin resistance. Nat Med. 2015 21(2): 159-65.

PubMed Abstract | Publisher Full Text | Free Full Text | F1000 Recommendation

80. Schote AB, Turner JD, Schiltz J, et al.: Nuclear receptors in human immune cells: expression and correlations. Mol Immunol. 2007; 44(6): 1436-45. PubMed Abstract | Publisher Full Text

81. Jin J, Hou Q, Mullen TD, et al: Ceramide generated by sphingomyelin hydrolysis and the salvage pathway is involved in hypoxia/reoxygenationinduced Bax redistribution to mitochondria in NT-2 cells. J Biol Chem. 2008; 283(39): 26509-17.

PubMed Abstract | Publisher Full Text | Free Full Text

82. Kartal Yandim M, Apohan E, Baran Y: Therapeutic potential of targeting ceramide/glucosylceramide pathway in cancer. Cancer Chemother Pharmacol.
2013; 71(1): 13-20.

PubMed Abstract | Publisher Full Text

83. Liu YY, Hill RA, Li YT: Ceramide glycosylation catalyzed by glucosylceramide synthase and cancer drug resistance. Adv Cancer Res. 2013; 117: 59-89. PubMed Abstract | Publisher Full Text | Free Full Text

84. Bragazzi Cunha J, Wobus CE: Select membrane proteins modulate MNV-1 infection of macrophages and dendritic cells in a cell type-specific manner. Virus Res. 2016; 222: 64-70.

PubMed Abstract | Publisher Full Text

85. Comas-Casellas E, Martinez-Barriocanal Á, Miró F, et al.: Cloning and characterization of CD300d, a novel member of the human CD300 family of immune receptors. J Biol Chem. 2012; 287(13): 9682-93. PubMed Abstract | Publisher Full Text | Free Full Text

86. Makino A, Shimojima M, Miyazawa T, et al.: Junctional adhesion molecule 1 is a unctional receptor for feline calicivirus. J Virol. 2006; 80(9): 4482-90. PubMed Abstract | Publisher Full Text | Free Full Text

87. Clark GJ, Ju X, Azlan M, et al:: The CD300 molecules regulate monocyte and dendritic cell functions. Immunobiology. 2009; 214(9-10): 730-6. PubMed Abstract | Publisher Full Text

88. Asai T, Morrison SL: The SRC family tyrosine kinase HCK and the ETS family transcription factors SPIB and EHF regulate transcytosis across a human follicle-associated epithelium model. J Biol Chem. 2013; 288(15): 10395-405. PubMed Abstract | Publisher Full Text | Free Full Text

89. Gonzalez-Hernandez MB, Liu T, Blanco LP, et al.: Murine norovirus transcytosis across an in vitro polarized murine intestinal epithelial monolayer is mediated by M-like cells. J Virol. 2013; 87(23): 12685-93. PubMed Abstract | Publisher Full Text | Free Full Text

90. Gonzalez-Hernandez MB, Liu T, Payne HC, et al.: Efficient norovirus and reovirus replication in the mouse intestine requires microfold (M) cells. $J$ Virol. 2014; 88(12): 6934-43.

PubMed Abstract | Publisher Full Text | Free Full Text

91. Kolawole AO, Gonzalez-Hernandez MB, Turula $\mathrm{H}$, et al:: Oral Norovirus Infection Is Blocked in Mice Lacking Peyer's Patches and Mature M Cells. J Virol. 2015; 90(3): 1499-506.

PubMed Abstract | Publisher Full Text | Free Full Text

92. $\mathrm{F}$ Yotsumoto $\mathrm{K}$, Okoshi $\mathrm{Y}$, Shibuya $\mathrm{K}$, et al.: Paired activating and inhibitory immunoglobulin-like receptors, MAIR-I and MAIR-II, regulate mast cell and macrophage activation. J Exp Med. 2003; 198(2): 223-33.

PubMed Abstract | Publisher Full Text | Free Full Text | F1000 Recommendation

93. Nakahashi C, Tahara-Hanaoka S, Totsuka N, et al:: Dual assemblies of an activating immune receptor, MAIR-II, with ITAM-bearing adapters DAP12 and FcRgamma chain on peritoneal macrophages. J Immunol. 2007; 178(2): 765-70. PubMed Abstract | Publisher Full Text

94. Newman KL, Moe CL, Kirby AE, et al.: Norovirus in symptomatic and asymptomatic individuals: cytokines and viral shedding. Clin Exp Immunol. 2016; 184(3): 347-57.

PubMed Abstract | Publisher Full Text | Free Full Text

95. Chen SM, Lin CP. Tsai JD, et al: The significance of serum and fecal levels of interleukin- 6 and interleukin-8 in hospitalized children with acute rotavirus and norovirus gastroenteritis. Pediatr Neonatol. 2014; 55(2): 120-6. PubMed Abstract | Publisher Full Text

96. F Kuss SK, Best GT, Etheredge CA, et al:: Intestinal microbiota promote enteric virus replication and systemic pathogenesis. Science. 2011; 334(6053): $249-52$.

PubMed Abstract | Publisher Full Text | Free Full Text | F1000 Recommendation

97. F Kane M, Case LK, Kopaskie K, et al.: Successful transmission of a retrovirus depends on the commensal microbiota. Science. 2011; 334(6053): 245-9. PubMed Abstract | Publisher Full Text | Free Full Text | F1000 Recommendation

98. Karst SM: The influence of commensal bacteria on infection with enteric viruses. Nat Rev Microbiol. 2016; 14(4): 197-204 PubMed Abstract | Publisher Full Text | Free Full Tex

99. Li D, Breiman A, le Pendu J, et al.: Binding to histo-blood group antigen-expressing bacteria protects human norovirus from acute heat stress. Front Microbiol. 2015 6: 659 .

PubMed Abstract | Publisher Full Text | Free Full Text

100. Lei S, Samuel H, Twitchell E, et al.: Enterobacter cloacae inhibits human norovirus infectivity in gnotobiotic pigs. Sci Rep. 2016; 6: 25017. PubMed Abstract | Publisher Full Text | Free Full Text

101. Robinson CM, Jesudhasan PR, Pfeiffer JK: Bacterial lipopolysaccharide binding enhances virion stability and promotes environmental fitness of an enteric virus. Cell Host Microbe. 2014; 15(1): 36-46. PubMed Abstract | Publisher Full Text | Free Full Text

102. $F$ Kernbauer E, Ding $Y$, Cadwell K: An enteric virus can replace the beneficial function of commensal bacteria. Nature. 2014; 516(7529): 94-8. PublMed Abstract | Publisher Full Text | Free Full Text | F1000 Recommendation

103. F Baldridge MT, Nice TJ, McCune BT, et al: Commensal microbes and interferon- $\lambda$ determine persistence of enteric murine norovirus infection. Science. 2015; 347(6219): 266-9.

PubMed Abstract | Publisher Full Text | Free Full Text | F1000 Recommendation

104. Nagata S, Asahara T, Ohta T, et al.: Effect of the continuous intake of probioticfermented milk containing Lactobacillus casei strain Shirota on fever in a mass outbreak of norovirus gastroenteritis and the faecal microflora in a 
health service facility for the aged. Br J Nutr. 2011; 106(4): 549-56. PubMed Abstract | Publisher Full Text

105. F Lee H, Ko G: Antiviral effect of vitamin A on norovirus infection via modulation of the gut microbiome. Sci Rep. 2016; 6: 25835 . PubMed Abstract | Publisher Full Text | Free Full Text | F1000 Recommendation

106. F Di Meng, Newburg DS, Young C, et al:: Bacterial symbionts induce a FUT2-dependent fucosylated niche on colonic epithelium via ERK and JNK signaling. Am J Physiol Gastrointest Liver Physiol. 2007; 293(4): G780-7. PubMed Abstract | Publisher Full Text | F1000 Recommendation

107. F Ruvoën-Clouet N, Magalhaes A, Marcos-Silva L, et al.: Increase in genogroup I..4 norovirus host spectrum by CagA-positive Helicobacter pylori infection. $J$ Infect Dis. 2014; 210(2): 183-91.

PubMed Abstract | Publisher Full Text | F1000 Recommendation

108. Wacklin P, Tuimala J, Nikkilä J, et al.: Faecal microbiota composition in adults is associated with the FUT2 gene determining the secretor status. PLOS One. 2014; 9(4): e94863.

PubMed Abstract | Publisher Full Text | Free Full Text

109. Wacklin P, Mäkivuokko H, Alakulppi N, et al.: Secretor genotype (FUT2 gene) is strongly associated with the composition of Bifidobacteria in the human intestine. PLoS One. 2011; 6(5): e20113. PubMed Abstract | Publisher Full Text | Free Full Text

110. Kashyap PC, Marcobal A, Ursell LK, et al.: Genetically dictated change in hos mucus carbohydrate landscape exerts a diet-dependent effect on the gut microbiota. Proc Natl Acad Sci U S A. 2013; 110(42): 17059-64. PubMed Abstract | Publisher Full Text | Free Full Text

111. Izawa K, Kitaura J, Yamanishi $\mathrm{Y}$, et al.: Functional analysis of activating receptor LMIR4 as a counterpart of inhibitory receptor LMIR3. J Biol Chem. 2007; 282(25): 17997-8008.

PubMed Abstract | Publisher Full Tex

112. Borrego $F$ : The CD300 molecules: an emerging family of regulators of the immune system. Blood. 2013; 121(11): 1951-60. PubMed Abstract | Publisher Full Text | Free Full Text

113. Ejarque-Ortiz A, Solà C, Martinez-Barriocanal Á, et al.: The Receptor CMRF35-Like Molecule-1 (CLM-1) Enhances the Production of LPS-Induced Pro-Inflammatory Mediators during Microglial Activation. PLoS One. 2015; 10(4): e0123928. PubMed Abstract | Publisher Full Text | Free Full Text

114. Fang $\mathrm{H}$, Tan $\mathrm{M}, \mathrm{Xia} \mathbf{M}$, et al.: Norovirus $\mathbf{P}$ particle efficiently elicits innate, humoral and cellular immunity. PLoS One. 2013; 8(4): e63269. PubMed Abstract | Publisher Full Text | Free Full Text

115. Hsu CC, Paik J, Treuting PM, et al.: Infection with murine norovirus $\mathbf{4}$ does not alter Helicobacter-induced inflammatory bowel disease in $/ 110(-/-)$ mice. Comp Med. 2014; 64(4): 256-63. PubMed Abstract | Free Full Text

116. Hanasaki K, Varki A, Stamenkovic I, et al:: Cytokine-induced beta-galactoside alpha-2,6-sialyltransferase in human endothelial cells mediates alpha 2,6-sialylation of adhesion molecules and CD22 ligands. J Biol Chem. 1994; 269(14): 10637-43.

PubMed Abstract
117. Colomb F, Vidal O, Bobowski M, et al.: TNF induces the expression of the sialyltransferase ST3Gal IV in human bronchial mucosa via MSK1/2 protein kinases and increases FliD/sialyl-Lewis ${ }^{\mathrm{x}}$-mediated adhesion of Pseudomonas aeruginosa. Biochem J. 2014; 457(1): 79-87. PubMed Abstract | Publisher Full Text

118. Chatterjee S, Pandey A: The Yin and Yang of lactosylceramide metabolism: implications in cell function. Biochim Biophys Acta. 2008; 1780(3): 370-82. PubMed Abstract | Publisher Full Text

119. Taube S, Perry JW, McGreevy E, et al.: Murine noroviruses bind glycolipid and glycoprotein attachment receptors in a strain-dependent manner. J Virol. 2012; 86(10): 5584-93.

PubMed Abstract | Publisher Full Text | Free Full Text

120. F Agresti JJ, Antipov E, Abate AR, et al.: Ultrahigh-throughput screening in drop-based microfluidics for directed evolution. Proc Natl Acad Sci U S A. 2010; 107(9): 4004-9.

PubMed Abstract | Publisher Full Text | Free Full Text | F1000 Recommendation

121. F Price AK, Paegel BM: Discovery in Droplets. Anal Chem. 2016; 88(1): 339-53. PubMed Abstract | Publisher Full Text | Free Full Text | F1000 Recommendation

122. Mazutis L, Gilbert J, Ung WL, et al.: Single-cell analysis and sorting using droplet-based microfluidics. Nat Protoc. 2013; 8(5): 870-91. PubMed Abstract | Publisher Full Text | Free Full Text

123. Chiu DT, Lorenz RM, Jeffries GD: Droplets for ultrasmall-volume analysis. Anal Chem. 2009; 81(13): 5111-8. PubMed Abstract | Publisher Full Text

124. F Wen N, Zhao Z, Fan B, et al.: Development of Droplet Microfluidics Enabling High-Throughput Single-Cell Analysis. Molecules. 2016; 21(7): pii: E881. PubMed Abstract | Publisher Full Text | F1000 Recommendation

125. Livak-Dahl E, Sinn I, Burns M: Microfluidic chemical analysis systems. Annu Rev Chem Biomol Eng. 2011; 2: 325-53. PubMed Abstract | Publisher Full Text

126. Guo MT, Rotem A, Heyman JA, et al:: Droplet microfluidics for high-throughput biological assays. Lab Chip. 2012; 12(12): 2146-55 PubMed Abstract | Publisher Full Text

127. Bull RA, Hansman GS, Clancy LE et al: Norovirus recombination in ORF1/ORF2 overlap. Emerg Infect Dis. 2005; 11(7): 1079-85. PubMed Abstract | Publisher Full Text | Free Full Text

128. Mathijs $\mathrm{E}$, Muylkens $\mathrm{B}$, Mauroy $\mathrm{A}$, et al.: Experimental evidence of recombination in murine noroviruses. J Gen Virol. 2010; 91(pt 11): 2723-33. PubMed Abstract | Publisher Full Text

129. F Ishii S, Kitamura G, Segawa T, et al: Microfluidic quantitative PCR for simultaneous quantification of multiple viruses in environmental water samples. Appl Environ Microbiol. 2014; 80(24): 7505-11. PubMed Abstract | Publisher Full Text | Free Full Text | F1000 Recommendation

130. Connelly JT, Kondapalli S, Skoupi M, et al:: Micro-total analysis system for virus detection: microfluidic pre-concentration coupled to liposome-based detection. Anal Bioanal Chem. 2012; 402(1): 315-23. PublMed Abstract | Publisher Full Text 


\section{Open Peer Review}

\section{Current Peer Review Status:}

\section{Editorial Note on the Review Process}

Faculty Reviews are review articles written by the prestigious Members of Faculty Opinions. The articles are commissioned and peer reviewed before publication to ensure that the final, published version is comprehensive and accessible. The reviewers who approved the final version are listed with their names and affiliations.

\section{The reviewers who approved this article are:}

\section{Version 1}

\section{Jan Vinjé}

National Calicivirus Laboratory, Centers for Disease Control and Prevention, Atlanda, GA, USA

Competing Interests: No competing interests were disclosed.

\section{Grant Hansman}

Heidelberg University, Heidelberg, Germany

Competing Interests: No competing interests were disclosed.

The benefits of publishing with F1000Research:

- Your article is published within days, with no editorial bias

- You can publish traditional articles, null/negative results, case reports, data notes and more

- The peer review process is transparent and collaborative

- Your article is indexed in PubMed after passing peer review

- Dedicated customer support at every stage

For pre-submission enquiries, contact research@f1000.com 